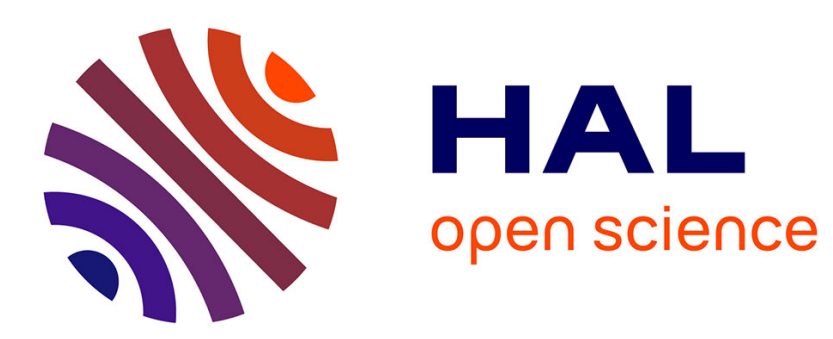

\title{
A dilution refrigerator insert for standard ILL cryostats
}

\author{
K. Neumaier, A. Heidemann, A. Magerl
}

\section{To cite this version:}

K. Neumaier, A. Heidemann, A. Magerl. A dilution refrigerator insert for standard ILL cryostats. Revue de Physique Appliquée, 1984, 19 (9), pp.773-774. 10.1051/rphysap:01984001909077300 . jpa00245257

\section{HAL Id: jpa-00245257 https://hal.science/jpa-00245257}

Submitted on 1 Jan 1984

HAL is a multi-disciplinary open access archive for the deposit and dissemination of scientific research documents, whether they are published or not. The documents may come from teaching and research institutions in France or abroad, or from public or private research centers.
L'archive ouverte pluridisciplinaire HAL, est destinée au dépôt et à la diffusion de documents scientifiques de niveau recherche, publiés ou non, émanant des établissements d'enseignement et de recherche français ou étrangers, des laboratoires publics ou privés. 


\title{
A dilution refrigerator insert for standard ILL cryostats
}

\author{
K. Neumaier \\ WMI Garching, F.R.G. \\ A. Heidemann and A. Magerl \\ Institut Laue-Langevin, 156X, 38042 Grenoble Cedex, France
}

\begin{abstract}
Résumé. - Pour étendre la gamme de température des cryostats standards ILL (300-1,2 K) on a remplacé le porteéchantillon par un insert à dilution, avec une température minimale de $19 \mathrm{mK}$ et une puissance frigorifique de $23 \mu \mathrm{W}$ à $0,1 \mathrm{~K}$.
\end{abstract}

Abstract. - In order to extend the temperature range of Standard ILL cryostats (300-1.2 K) the sample stick was replaced by a dilution refrigerator insert with a minimum no-lead temperature of $19 \mathrm{mK}$ and a cooling power of $23 \mu \mathrm{W}$ at $0.1 \mathrm{~K}$.

In order to extend the temperature range of standard ILL cryostats (300-1.2 K) to lower temperatures, we replaced the sample stick by a dilution refrigerator insert (Fig. 1). The large cooling power $(15 \mathrm{~mW}$ at $1.5 \mathrm{~K}$ ) of the ILL cryostats allows to precool and liquify the incoming $\mathrm{He}^{3}$ of the dilution refrigerator. The tubular heat exchanger is constructed as follows. A Cu-Ni tube $0.6 / 0.4 \mathrm{~mm}$ (o.d., i.d.), $1.5 \mathrm{~m}$ long with a manganin wire of $0.25 \mathrm{~mm}$ inserted and a brass tube of $1.5 \mathrm{~mm}$ o.d. and $1.4 \mathrm{~mm}$ i.d., $3 \mathrm{~m}$ long are wound around a piano wire of $1.1 \mathrm{~mm}$ to form a coil with an overall length of about $1 \mathrm{~m}$. This coil is inserted into an annealed brass tube of $3 \mathrm{~mm}$ o.d. and $2.6 \mathrm{~mm}$ i.d. The concentric tubes are again wound into a coil of about $32 \mathrm{~mm}$ in diameter. The mixing chamber has a sintered copper heat exchanger with a surface of $\sim 5 \mathrm{~m}^{2}$ (measured in situ).

Circulating $\mathrm{He}^{3}$ with a $12 \mathrm{~m}^{3} / \mathrm{h}$ pump (Alcatel $2012 \mathrm{H})$ a minimum no-load temperature of $19 \mathrm{mK}$ was attained. The cooling power $(23 \mu \mathrm{W}$ at $0.1 \mathrm{~K}$, Fig. 2) was measured at the outside of the mixing chamber. The cooling time from room temperature to $30 \mathrm{mK}$ is typically 6 hours.

The insert is suitable for a large variety of instruments (TOF, triple axis, backscattering, powder diffractometer) and for sample sizes up to $50 \mathrm{~mm} \times$ $38 \mathrm{~mm}^{2}$.

For the next generation the following improvements are planned :

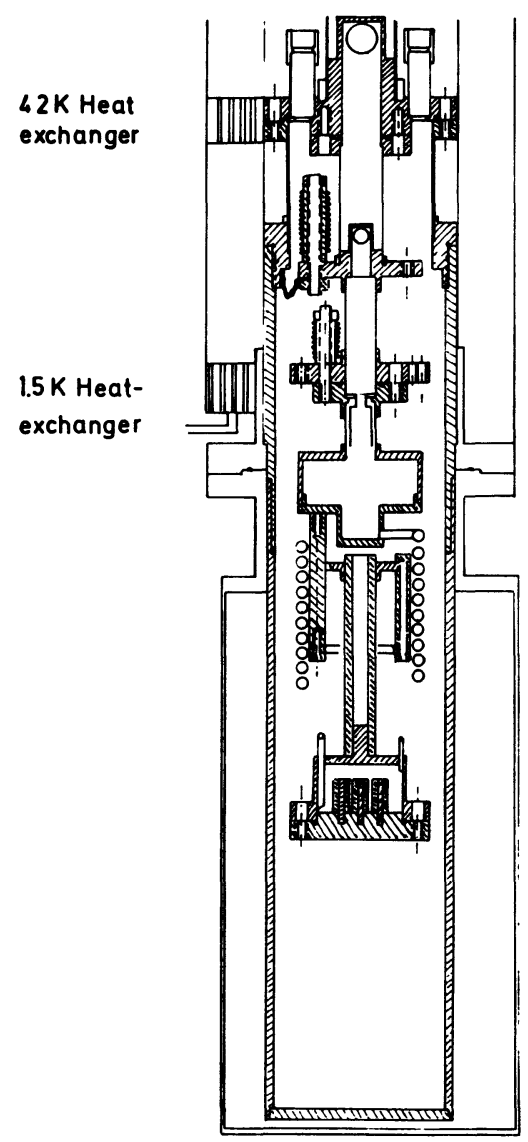

Fig. 1. 
1) An internal condensation stage. The incoming compressed $\mathrm{He}^{3}$ gas will be cooled down and liquified by the cold low pressure $\mathrm{He}^{3}$ gas in a counterflow heat exchanger. That allows to operate the dilution refrigerator from $4.2 \mathrm{~K}$ of a normal $\mathrm{He}^{4}$ bath [1] 2) A step heat exchanger with sintered copper $\left(2 \times 5 \mathrm{~m}^{2}\right.$ exchange area) will increase the cooling power below $50 \mathrm{mK}$ and lower $T_{\min }$ to $<15 \mathrm{mK}$.

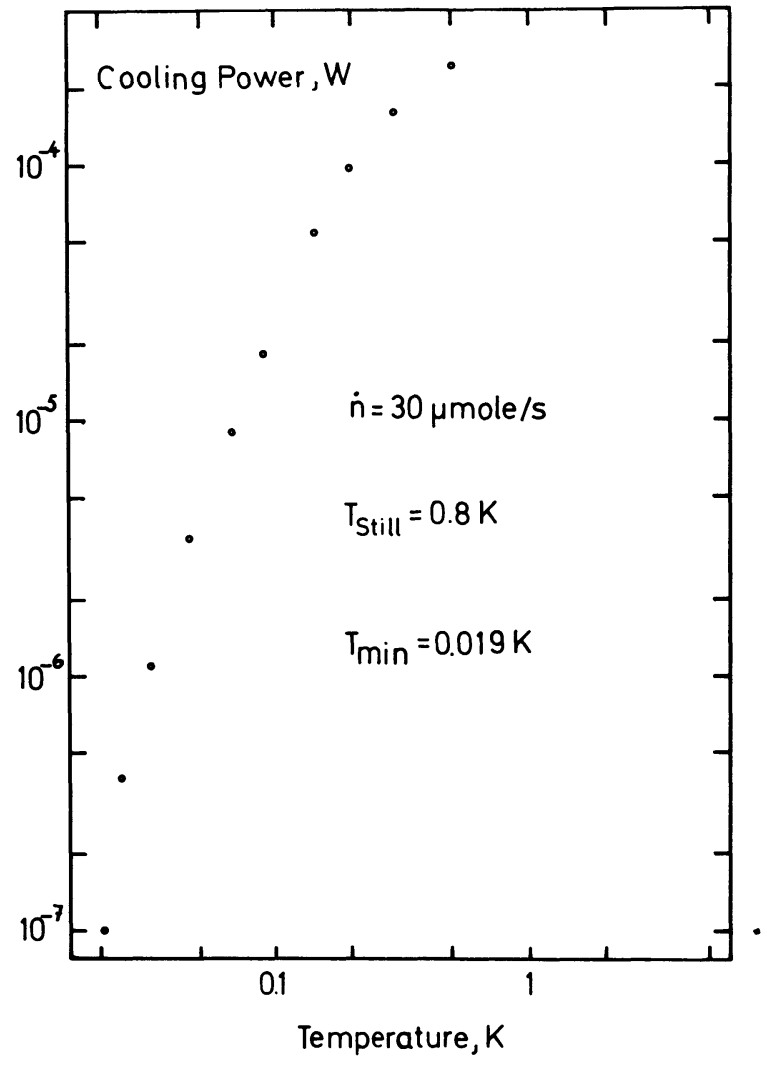

Fig. 2.

\section{References}

[1] Kraus, I., Cryogenics 17 (1977) 173. 